\title{
K-Ar ages of the Auckland geomagnetic excursions
}

\author{
Nobutatsu Mochizuki ${ }^{1}$, Hideo Tsunakawa ${ }^{1}$, Hidetoshi Shibuya $^{2}$, Takahiro Tagami $^{3}$, \\ Ayako Ozawa ${ }^{3}$, John Cassidy ${ }^{4}$, and Ian E. M. Smith ${ }^{4}$ \\ ${ }^{1}$ Department of Earth and Planetary Sciences, Tokyo Institute of Technology, Tokyo 152-8551, Japan \\ ${ }^{2}$ Department of Earth Sciences, Kumamoto University, Kumamoto 860-8555, Japan \\ ${ }^{3}$ Division of Earth and Planetary Sciences, Graduate School of Science, Kyoto University, Kyoto 606-8502, Japan \\ ${ }^{4}$ Department of Geology, University of Auckland, PO Box 92019, Auckland, New Zealand
}

(Received January 15, 2004; Revised February 20, 2004; Accepted February 20, 2004)

\begin{abstract}
K-Ar age determinations were made on two monogenetic volcanoes in the Auckland volcanic field, New Zealand, which have recorded the Auckland geomagnetic excursions. For the Wiri volcano with the north-down intermediate paleomagnetic direction, five samples gave a weighted mean age of $27 \pm 5(1 \sigma) \mathrm{ka}$. For the Hampton Park volcano with the west-up intermediate direction, three samples gave a weighted mean of $55 \pm 5(1 \sigma) \mathrm{ka}$. Since these two $\mathrm{K}-\mathrm{Ar}$ ages are distinguished at $2 \sigma$ level, it is inferred that at least two geomagnetic excursions can be recognized in Auckland. The age of the Hampton Park is barely distinguished from the established age range of the Laschamp excursion (39-45 ka) at $2 \sigma$ level. The age of the Wiri coincides with the age of c. $30 \mathrm{ka}$ in which excursions have been found from sedimentary and volcanic records. The reported excursions from volcanic rocks show a VGP cluster in the central to northern Pacific region which is distinct from the VGP paths or clusters during polarity reversals.
\end{abstract}

Key words: K-Ar age, Auckland geomagnetic excursion, Auckland volcanic field.

\section{Introduction}

The geomagnetic excursion is a phenomenon showing a larger swing of geomagnetic field from the geocentric axial dipole field than the secular variation. Typically within a short period (e.g., 1500 years, Laj et al., 2000) the virtual geomagnetic pole (VGP) departs more than $45^{\circ}$ from the geographic pole and then returns to the pre-existing polarity (e.g., Verosub and Banerjee, 1977). It is regarded as one of the characteristic behaviors of the geodynamo that creates the earth's magnetic field.

Several geomagnetic excursions have been reported for the past $80 \mathrm{ka}$, for example, the Laschamp excursion (Bonhommet and Zähringer, 1969) and the Mono Lake excursion (Denham and Cox, 1971). Shibuya et al. (1992) also reported intermediate paleomagnetic field directions from six monogenetic volcanoes in the Auckland volcanic field, New Zealand. These intermediate directions were classified into three groups: a north-down direction observed from three volcanoes, a west-up one from two volcanoes, and a southup one from one volcano (Fig. 1). It should be noted that the Auckland excursions were recorded in fresh alkali basaltic lavas of multiple monogenetic volcanoes. Therefore, they can provide an excellent opportunity to reveal details of the geomagnetic excursions using both radiometric ages and reliable paleomagnetic data.

In this study, we determined new K-Ar ages for two volcanoes: Wiri volcano from the north-down group and Hampton Park volcano from the west-up group. We report these K-Ar

Copy right (c) The Society of Geomagnetism and Earth, Planetary and Space Sciences (SGEPSS); The Seismological Society of Japan; The Volcanological Society of Japan; The Geodetic Society of Japan; The Japanese Society for Planetary Sciences; TERRAPUB. dates, and also discuss the geomagnetic features during the excursions based on the ages and paleodirections.

\section{Auckland Volcanic Field and Sampling}

The Auckland volcanic field is one of the predominantly basaltic Pliocene to recent intraplate volcanic fields in the northern North Island, New Zealand (Smith, 1989). It has produced basalts of characteristic intraplate type chemistry during a period of stable to mildly extensional tectonics, about $400 \mathrm{~km}$ behind the present active convergent plate boundary (Kermode, 1992). It has been suggested that the Auckland volcanic field is the result of hotspot activity (e.g., Tatsumi and Tsunakawa, 1992). The volcanic field comprises about 50 volcanoes within an area of $360 \mathrm{~km}^{2}$ (Fig. 1), and has been active for the last $250 \mathrm{ka}$ (Allen and Smith, 1994; Shane, 2002). The individual volcanoes are monogenetic, resulting from a single eruption or a very short sequence of eruptions (Kermode, 1992); rocks of the volcanic field are mostly alkali basalt and basanite (Smith, 1989).

Several ${ }^{14} \mathrm{C}$ ages (uncalibrated) and thermoluminescence (TL) ages have been reported for volcanoes in the Auckland volcanic field. For the north-down group, 25 and $28 \mathrm{ka}$ ${ }^{14} \mathrm{C}$ ages were reported for the Wiri volcano (Polach et al., 1969; Grant-Taylor and Rafter, 1971), 29 and $30 \mathrm{ka}{ }^{14} \mathrm{C}$ ages for the Crater Hill volcano (Searle, 1965; Grant-Taylor and Rafter, 1971), and 22 ka TL age for the Puketutu volcano (Wood, 1991). For the south-up group of the McLennan Hills volcano, $27 \mathrm{ka}{ }^{14} \mathrm{C}$ age (Polach et al., 1969) and $49 \mathrm{ka}$ TL age (Wood, 1991) are available. For the west-up group of two volcanoes, no radiometric age has been reported. McDougall et al. (1969) carried out K-Ar age determinations of whole rock samples from the Auckland basalts. Most 


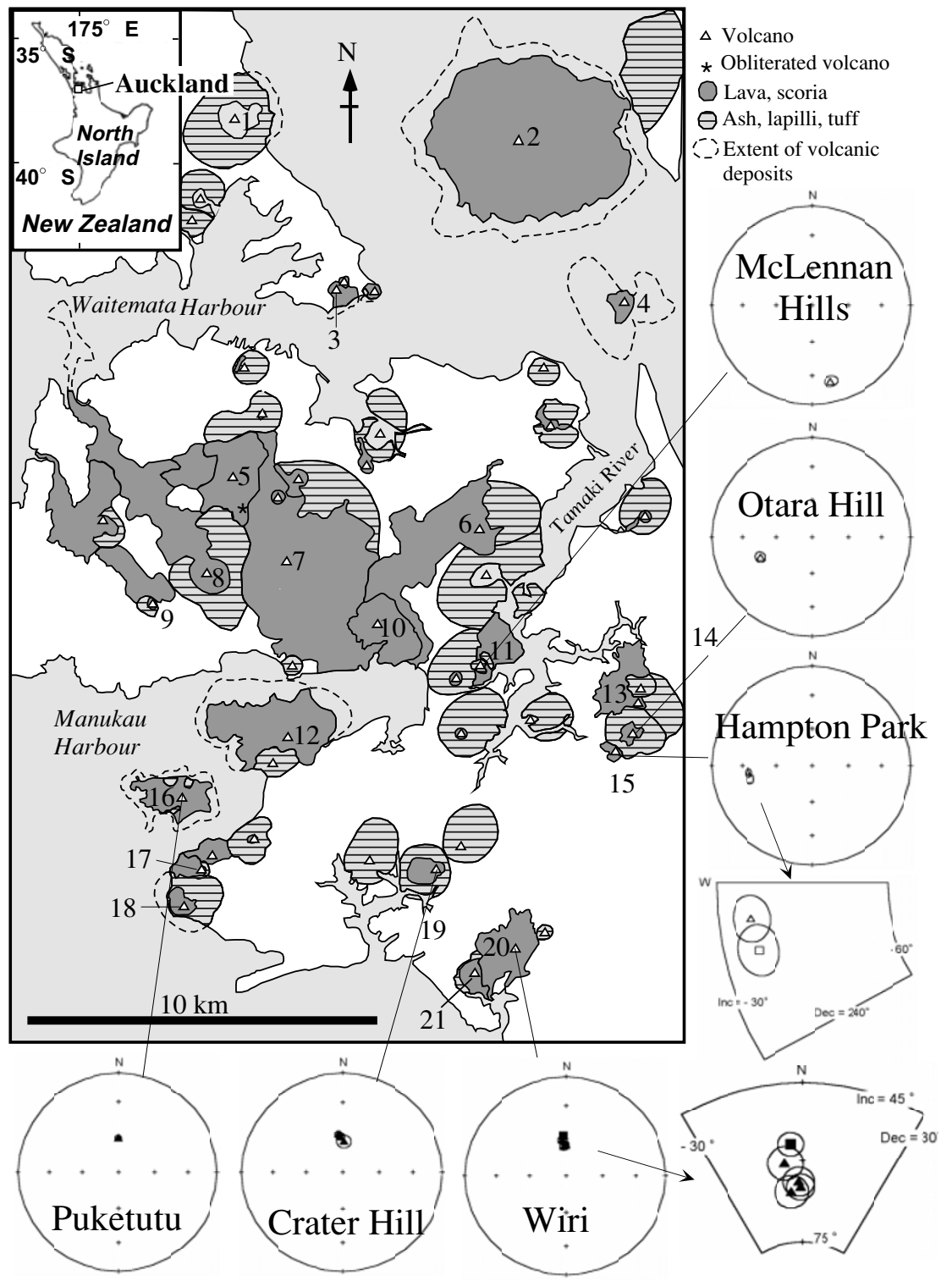

Fig. 1. Map of volcanoes in the Auckland volcanic field. Triangles indicate eruption centers of monogenetic volcanoes. Numbers are attached to the 21 volcanoes studied by Shibuya et al. (1992). The intermediate paleomagnetic directions from six volcanoes are shown in equal area projections (triangles, Shibuya et al., 1992). The mean directions in this study (squares) are also shown for Wiri and Hampton Park volcanoes. Closed and open symbols indicate positive and negative inclinations, respectively. This map is modified from Kermode (1992).

of their ages were obviously older than the reported ${ }^{14} \mathrm{C}$ ages, or in contradiction to the geological evidences. They suggested that the basalts commonly contained some amount of extraneous Ar which was carried in phenocrysts.

Samples were collected from the Wiri and Hampton Park volcanoes in March of 2000. All the samples were fresh alkali basalts. For the Wiri volcano, eleven samples were collected from three sites, which were distributed along a 100 $m$ wide outcrop in the westernmost part of the Wiri quarry. One-inch oriented cores were also sampled from five sites of the same outcrop by using a portable engine drill and a sun or magnetic compass for paleomagnetic study. The four sites of Shibuya et al. (1992) were from a southern outcrop of the same quarry and from another quarry slightly south of the former one. For the Hampton Park volcano, thirteen samples were collected from a $20 \mathrm{~m}$ wide outcrop at the same site as Shibuya et al. (1992). Ten of the thirteen samples were oriented by a magnetic compass while the other three were collected for K-Ar dating with no orientation. One-inch paleomagnetic cores were cut in the laboratory from these oriented samples.

Paleomagnetic specimens were subjected to low temperature demagnetization at a liquid nitrogen temperature, and subsequently to alternating field demagnetization up to 140 or $160 \mathrm{mT}$ at 5 or $10 \mathrm{mT}$ intervals. Details of the remanence measurements are described in Yamamoto et al. (2002, 2003). The mean paleomagnetic directions were declination (D) $=-3.7^{\circ}$, inclination $(\mathrm{I})=56.8^{\circ}, \alpha_{95}=2.2^{\circ}(\mathrm{N}=11)$ for the Wiri volcano and $\mathrm{D}=-102.2^{\circ}, \mathrm{I}=-36.6^{\circ}, \alpha_{95}=3.7^{\circ}$ $(\mathrm{N}=10)$ for the Hampton Park volcano. These mean directions were almost the same as those determined by Shibuya et al. (1992) in Fig. 1. A comprehensive report of paleomagnetism including paleointensities will be presented elsewhere (Mochizuki et al., in preparation). 


\section{K-Ar Dating Method and Results}

Fresh internal fragments (70-150 g) were firstly cut from the samples then crushed and sieved to $0.25-0.50 \mathrm{~mm}$ in diameter. The sieved samples were ultrasonically washed in both deionized water and acetone. Phenocrysts were removed from the sieved samples using a Franz isodynamic separator to avoid possible extraneous ${ }^{40} \mathrm{Ar}$ in the phenocrysts (e.g., Dalrymple and Lanphere, 1969) which were suggested to contaminate the Auckland basalts (McDougall et al., 1969). We repeated the separation procedure until no grains of larger than half-sized phenocrysts were found in the part $(\sim 0.1 \mathrm{~g})$ of the sieved samples using a stereoscopic zoom microscope. The final aliquots were composed mostly of groundmass grains. Aliquots for potassium analyses were then ground by an agate mortar.

Potassium and argon measurements were performed at the geochronology laboratory of Kyoto University. We determined $\mathrm{K}_{2} \mathrm{O}$ contents twice for each sample by a flame emission photometry, following the procedure of Matsumoto (1989). The average of two results was used for the age calculation. The experimental error is estimated to be about $1 \%$. $\mathrm{K}_{2} \mathrm{O}$ contents of the standard rock samples were measured during the same runs: $1.771 \pm 0.008 \%(\mathrm{~N}=6)$ for JA-2 and $0.774 \pm 0.006 \%(\mathrm{~N}=8)$ for JB-3. These showed no systematic errors compared with the reported values (Matsumoto, 1989; JA-2: $1.77 \pm 0.01 \%$, JB-3: $0.774 \pm 0.002 \%$ ).

Radiogenic ${ }^{40} \mathrm{Ar}$ was determined with a VG3600 mass spectrometer by the unspiked sensitivity method. The initial ${ }^{40} \mathrm{Ar} /{ }^{36} \mathrm{Ar}$ ratio was corrected for the natural mass fractionation by a mass fractionation correction procedure (MFCP: Itaya and Nagao, 1988; Takaoka et al., 1989; Matsumoto et al., 1989a). Details of the Ar measurement procedures are described in Sudo et al. (1996).

In this study, standard-air measurements indicated a constant mass discrimination factor within analytical errors throughout the experiments. In the sample measurements, we conducted preliminary Ar measurements for about $1.5 \mathrm{~g}$ aliquot of individual samples. Based on the results, the mass of each sample was adjusted to a suitable quantity (3-7 g) for giving sufficient ${ }^{38} \mathrm{Ar}$ signal comparable to that in the standard-air analysis.

The K-Ar dating results for all the samples measured are listed in Table 1. K-Ar ages with MFCP are reasonably consistent (11-39 ka) for five samples collected at three sites of the Wiri volcano, and they yield a weighted mean of 27 $\pm 5(1 \sigma) \mathrm{ka}$. If MFCP is not applied, the uncorrected ages give a weighed mean of $30 \pm 1(1 \sigma) \mathrm{ka}$. These two mean ages are similar to each other at $1 \sigma$ level and agree with the reported ${ }^{14} \mathrm{C}$ ages (uncalibrated ages: 25 and $28 \mathrm{ka}$ ). In the later discussion, we use the weighted mean age with MFCP (27 $\pm 5 \mathrm{ka}$ ) since historic lavas usually show natural mass fractionation of initial Ar isotopic ratios (Matsumoto et al., 1989b). The increase in standard deviation after MFCP might imply that the effect of natural mass fractionation was small and MFCP introduced unbiased random errors. For future studies, we have also listed $\mathrm{K}-\mathrm{Ar}$ age data without MFCP in Table 1. Since the ${ }^{14} \mathrm{C}$ and TL ages reported in the previous studies are less reliable, we discuss the Auckland excursions on the basis of the K-Ar ages in this study.

$\mathrm{K}-\mathrm{Ar}$ ages of three samples of the Hampton Park volcano are concordant $(52-59 \mathrm{ka})$ regardless of MFCP. It indicates that the initial ${ }^{40} \mathrm{Ar} /{ }^{36} \mathrm{Ar}$ ratios at the eruption were not significantly different from the atmospheric ${ }^{40} \mathrm{Ar} /{ }^{36} \mathrm{Ar}$. In this study, we adopted a weighted mean with MFCP of $55 \pm 5$ $(1 \sigma) \mathrm{ka}$ as the formation age of the Hampton Park volcano.

\section{Discussion}

These K-Ar ages indicate that the west-up intermediate geomagnetic direction of the Hampton Park volcano occurred at $55 \mathrm{ka}$ and the north-down direction of the Wiri volcano at $27 \mathrm{ka}$. These $\mathrm{K}-\mathrm{Ar}$ dates were measured on the fresh groundmass suggesting no loss of $\mathrm{Ar}$ and/or $\mathrm{K}$ due to weathering. Also, possible extraneous Ar was avoided by almost complete removal of large phenocrysts from the samples. Therefore, the K-Ar ages obtained in this study are considered to have good accuracy. Since the ages determined for the two volcanoes are distinguished at $2 \sigma$ level, it is inferred that at least two excursions have been recorded in the Auckland volcanic field. We discuss below the morphology of the geomagnetic field associated with both $27 \mathrm{ka}$ and 55 ka excursions.

The Laschamp excursion found from lavas in France has been dated by various methods (e.g., Chauvin et al., 1989; Levi et al., 1990). From all the data, its age is likely to be within the limits of 39 and $45 \mathrm{ka}$ (Laj et al., 2000; Kent et al., 2002). Although our K-Ar age of the Hampton Park volcano $(55 \mathrm{ka})$ is slightly older than the established age range of the Laschamp, they are barely distinguishable at $2 \sigma$ level. It is thus possible to tentatively correlate the Hampton Park record with the Laschamp. If they recorded different excursions, it may suggest that excursions occurred at 55, $39-45$ and $27 \mathrm{ka}$ with an interval of $10^{4}$ years.

The age of Wiri (27 ka) corresponds to the age of c. 30 $\mathrm{ka}$ in which excursions have been recognized from sedimentary and volcanic records. The Mono Lake excursion was reported from lacustrine sediments in western America. Its age was previously estimated as c. 28 ka (Liddicoat, 1992) though it has been in debate (e.g., Kent et al., 2002). Recently, a ${ }^{14} \mathrm{C}$ age of $28.6 \mathrm{ka}$ (calibrated age: $31.7 \mathrm{ka}$ ) was determined for the volcanic tephra (Ash \#15) in the Pyramid Lake Basin of Nevada, which was formed at the middle of the Mono Lake excursion (Benson et al., 2003). Some paleomagnetic records in the other areas indicated excursions around 25-35 ka in the eastern Arctic Ocean (Nowaczyk and Knies, 2000) and at Kilauea volcano in Hawaii (Laj et al., 2002; Teanby et al., 2002). Carvallo et al. (2003) presented ${ }^{40} \mathrm{Ar} /{ }^{39} \mathrm{Ar}$ ages of $26 \pm 15$ and $18 \pm 9 \mathrm{ka}$ for two lavas with intermediate paleodirections from Amsterdam Island. Therefore, it is likely that the existence of c. 30 ka excursion is reasonably well established.

In Fig. 2, the VGP positions in this study are compared with those excursions reported from volcanic rocks. The VGPs of the Auckland excursions are located in (1) near eastern Africa, (2) central to northern Pacific Ocean and (3) southern Atlantic Ocean. Each appears to correlate with certain VGP clusters in Fig. 2, which are based on different sampling sites and/or ages. Cluster (1) may be close to the preferred longitudinal path in the eastern hemisphere (Laj et al., 1991). Cluster (3) is coincident with the VGP cluster during reversals (Hoffman, 1991), or the preferred path in the 


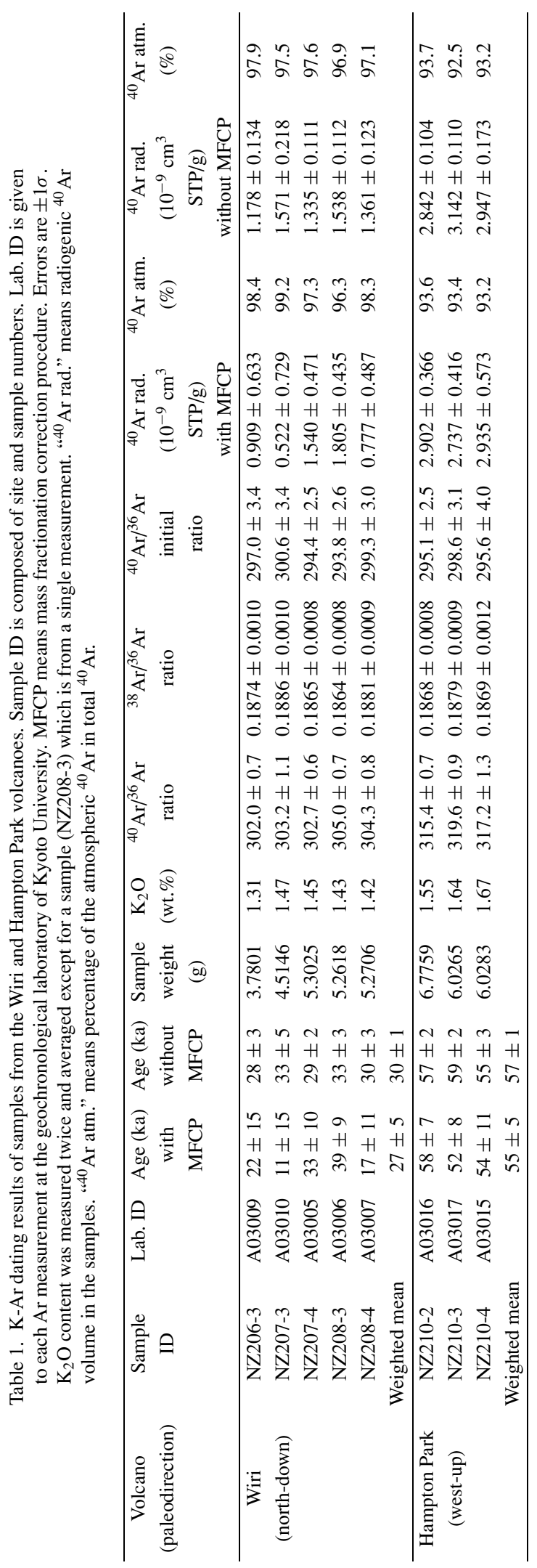




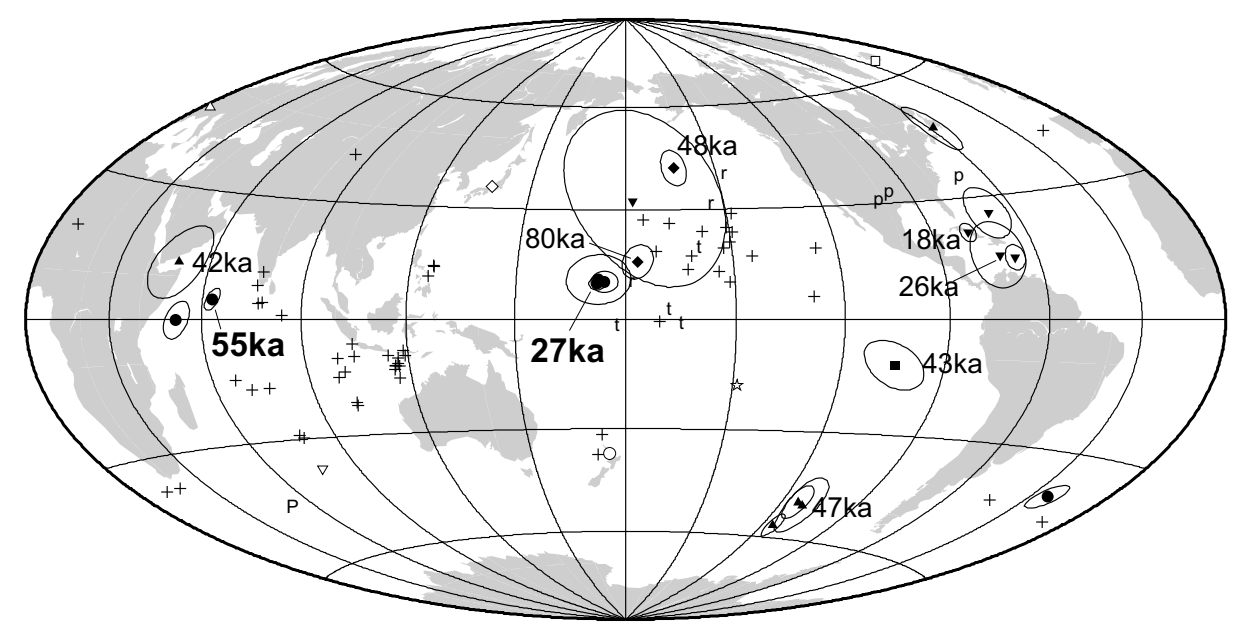

Fig. 2. Equal area projection of VGPs (closed symbols) of the young ( $\leq 80 \mathrm{ka}$ ) geomagnetic excursions reported from volcanic rocks. Open symbols represent the corresponding sampling sites. Excursional VGPs from New Zealand (circles: this study and Shibuya et al., 1992), France (triangles: Bonhommet and Zähringer, 1969; Roperch et al., 1988; Chauvin et al., 1989), Iceland (square: Levi et al., 1990), Japan (diamonds: Tanaka and Kobayashi, 2003) and Amsterdam Island (inverse triangles: Watkins and Nougier, 1973; Carvallo et al., 2003) are shown together with available K-Ar or ${ }^{40} \mathrm{Ar} /{ }^{39} \mathrm{Ar}$ ages. Also shown are intermediate VGPs $\left(-45^{\circ} \leq\right.$ latitude $\left.\leq 45^{\circ}\right)$ from Pliocene volcanic rocks in the Society Islands; Raiatea and Tahaa ("r" and " $t$ ": Yamamoto et al., 2002), Huahine ("+": Roperch and Duncan, 1990) and from Plio-Pleistocene lavas in Possession Island, Crozet Archipelago ("p": Camps et al., 2001). Star and "P" denote the positions of the Society Islands and Possession Island.

western hemisphere. However, cluster (2) is located quite differently from either those VGP paths or clusters during reversals.

The VGPs from the west-up group (55 ka) and that from the Louchadière lava (42 ka) in France (Chauvin et al., 1989) are located similarly near eastern Africa. If these recorded the same geomagnetic field, it might possibly reflect an equatorial dipole (Tanaka and Kobayashi, 2003). However, the other VGPs of 43-48 ka show a wide distribution (Fig. 2). The 27 ka excursion of the north-down group gives the VGP in the central Pacific region whereas the 26 ka excursion in Amsterdam Island shows the VGP in the westernmost region of the mid-Atlantic Ocean. These data suggest that the configuration of the geomagnetic field during excursions is not described by a stationary equatorial dipole field.

The central to northern Pacific VGP cluster (3) comes from excursional records in New Zealand (27 ka), Japan (48 and $80 \mathrm{ka}$ ), and Amsterdam Island (unknown age). It is noticeable that this VGP cluster is also indicated by the possible Pliocene excursions from volcanic rocks in the Society Islands: Tahaa (2.8-3.2 Ma) and Raiatea (2.44-2.75 Ma) by Yamamoto et al. (2002), and Huahine (2.91-3.08 Ma) by Roperch and Duncan (1990). As suggested by Carvallo et al. (2003), the VGP cluster from the Amsterdam excursion in the westernmost mid-Atlantic Ocean is also accompanied by VGPs of the Plio-Pleistocene excursion recorded in lavas on Possession Island in the Crozet Archipelago, India Ocean (Camps et al., 2001). These data may suggest that some common factors control the geomagnetic field during excursions.

\section{Conclusions}

We determined K-Ar ages of two Auckland monogenetic volcanoes recording intermediate directions of the geomagnetic field. The Hampton Park volcano with the west-up direction gave $55 \pm 5(1 \sigma) \mathrm{ka}(N=3)$, while the Wiri volcano with the north-down direction $27 \pm 5(1 \sigma) \mathrm{ka}(N=5)$.
These two ages are distinguished at $2 \sigma$ level and show that at least two geomagnetic excursions can be recognized in Auckland, New Zealand. The age of the Hampton Park volcano is barely distinguished from the established age range of the Laschamp excursion (39-45 ka) at $2 \sigma$ level. The age of the Wiri volcano corresponds to the age of c. $30 \mathrm{ka}$ in which excursions have been found in sediments and volcanic rocks in the other areas. For the VGPs of the reported excursions, there is a cluster in the central to northern Pacific region which is different from the VGP paths or clusters during polarity reversals.

Acknowledgments. We are grateful to Dr. K. Uto for helpful suggestions for K-Ar dating. We thank Dr. H. Tanaka and Dr. C. Carvallo for their reviews which helped us improve the manuscript.

\section{References}

Allen, S. R. and I. E. M. Smith, Eruption styles and volcanic hazard in the Auckland Volcanic Field, New Zealand, Geosci. Repts. Shizuoka Univ., 20, 5-14, 1994.

Benson, L., J. Liddicoat, J. Smoot, A. Sarna-Wojcicki, R. Negrini, and S. Lund, Age of the Mono Lake excursion and associated tephra, Quat. Sci. Rev., 22, 135-140, 2003.

Bonhommet, N. and J. Zähringer, Paleomagnetism and potassium argon age determinations of the Laschamp geomagnetic polarity event, Earth Planet. Sci. Lett., 6, 43-46, 1969.

Camps, P., B. Henry, M. Prévot, and L. Faynot, Geomagnetic paleosecular variation recorded in Plio-Pleistocene volcanic rocks from Possession Island (Crozet Archipelago, southern Indian Ocean), J. Geophys. Res., 106, 1961-1971, 2001.

Carvallo, C., P. Camps, G. Ruffet, B. Henry, and T. Poidras, Mono Lake or Laschamp geomagnetic event recorded from lava flows in Amsterdam Island (southeastern Indian Ocean), Geophys. J. Int., 154, 767-782, 2003.

Chauvin, A., R. A. Duncan, N. Bonhommet, and S. Levi, Paleointensity of the earth's magnetic field and K-Ar dating of the Louchadiere volcanic flow (Central France): new evidence for the Laschamp excursion, Geophys. Res. Lett., 16, 1189-1192, 1989.

Dalrymple, G. B. and M. A. Lanphere, Potassium-Argon Dating, 258 pp, Freeman, San Francisco, 1969.

Denham, C. R. and A. Cox, Evidence that the Laschamp polarity event did not occur 13,300-30,400 years ago, Earth Planet. Sci. Lett., 13, 181-190, 1971. 
Grant-Taylor, T. L. and T. A. Rafter, New Zealand radiocarbon age measurements, N. Z. J. Geol. Geophys., 14(2), 364-402, 1971.

Hoffman, K. A., Long-lived transitional states of the geomagnetic field and the two dynamo families, Nature, 354, 273-277, 1991.

Itaya, T. and K. Nagao, K-Ar age determination of volcanic rocks younger than 1 Ma, Mem. Geol. Soc. Japan, 29, 143-161, 1988 (in Japanese with English abstract).

Kent, D. V., S. R. Hemming, and B. D. Turrin, Laschamp Excursion at Mono Lake?, Earth Planet. Sci. Lett., 197, 151-164, 2002.

Kermode, L. O., Geology of the Auckland urban area, Scale 1:50000, Institute of Geological and Nuclear Sciences geological map2, 63 pp, 1 map, Institute of Geological and Nuclear Sciences Ltd., Lower Hutt, New Zealand, 1992.

Laj, C., A. Mazaud, R. Weeks, M. Fuller, and E. Herrero-Bervera, Geomagnetic reversal paths, Nature, 351, 447, 1991.

Laj, C., C. Kissel, A. Mazaud, J. E. T. Channell, and J. Beer, North Atlantic palaeointensity stack since $75 \mathrm{ka}$ (NAPIS-75) and the duration of the Laschamp event, Phil. Trans. R. Soc. Lond. A, 358, 1009-1025, 2000.

Laj, C., C. Kissel, V. Scao, J. Beer, D. M. Thomas, H. Guillou, R. Muscheler, and G. Wagner, Geomagnetic intensity and inclination variations at Hawaii for the past $98 \mathrm{kyr}$ from core SOH-4 (Big Island): a new study and a comparison with existing contemporary data, Phys. Earth Planet. Inter., 129, 205-243, 2002.

Levi, S., H. Audunsson, R. A. Duncan, L. Kristjansson, P.-Y. Gillot, and S. P. Jakobsson, Late Pleistocene geomagnetic excursion in Icelandic lavas: confirmation of the Laschamp geomagnetic excursion, Earth Planet. Sci. Lett., 96, 443-457, 1990.

Liddicoat, J. C., Mono Lake Excursion in Mono Basin, California, and at Carson Sink and Pyramid Lake Nevada, Geophys. J. Int., 108, 442-452, 1992.

Matsumoto, A., Improvement for determination of potassium in K-Ar dating, Bull. Geol. Surv. Japan, 40, 65-70, 1989 (in Japanese with English abstract).

Matsumoto, A., K. Uto, and K. Shibata, K-Ar dating by peak comparison method: new technique applicable to rocks younger than $0.5 \mathrm{Ma}$, Bull. Geol. Surv. Japan, 40, 565-579, 1989a.

Matsumoto, A., K. Uto, and K. Shibata, Argon isotopic ratios in historic lavas: importance of correction for the initial argon in K-Ar dating of young volcanic rocks, Mass Spectr., 37, 353-363, 1989b (in Japanese with English abstract)

McDougall, I., H. A. Polach, and J. J. Stipp, Excess radiogenic argon in young subaerial basalts from the Auckland volcanic field, New Zealand, Geochim. Cosmochim. Acta, 33, 1485-1520, 1969.

Nowaczyk, N. R. and J. Knies, Magnetostratigraphic results from the eastern Arctic Ocean: AMS ${ }^{14} \mathrm{C}$ ages and relative palaeointensity data of the Mono Lake and Laschamp geomagnetic reversal excursions, Geophys. J. Int., 140, 185-197, 2000.

Polach, H. A., J. Chappell, and J. F. Lovering, ANU Radiocarbon Data List III, Radiocarbon, 11, 245-262, 1969.

Roperch, P., N. Bonhommet, and S. Levi, Paleointensity of the earth's magnetic field during the Laschamp excursion and its geomagnetic implica- tions, Earth Planet. Sci. Lett., 88, 209-219, 1988.

Roperch, P. and R. A. Duncan, Records of geomagnetic reversals from volcanic islands of French Polynesia 1 . Paleomagnetic study of a polarity transition in a lava sequence from the island of Huahine, J. Geophys. Res., 95, 2713-2726, 1990.

Searle, E. J., Auckland volcanic district, New Zealand Dept. Sci. Indust. Res., 49, 90-103, 1965.

Shane, P., Maar drilling provides new insights into late Quaternary volcanism and paleoclimate in Auckland (Abstract), GSNZ Annual Conference Northland 2002, Geological Society of NZ Miscellaneous Publication, 112A, 50, 2002.

Shibuya, H., J. Cassidy, I. E. M. Smith, and T. Itaya, A geomagnetic excursion in the Brunhes epoch recorded in New Zealand basalts, Earth Planet. Sci. Lett., 111, 41-48, 1992.

Smith, I. E. M., North Island, in Intraplate volcanism in eastern Australia and New Zealand, edited by R.W. Johnson, pp. 157-162, Cambridge University Press, Cambridge, 1989.

Sudo, M., T. Tagami, K. Sato, N. Hasebe, and S. Nishimura, Calibration of a new Ar analytical system for the K-Ar dating method and analytical results of K-Ar age known samples, Mem. Fac. Sci. Kyoto Univ. Series Geol. Mineral., LVIII, 21-40, 1996.

Takaoka, N., K. Konno, Y. Oba, and T. Konda, K-Ar dating of lavas from Zao Volcano, North-eastern Japan, J. Geol. Soc. Japan, 95, 157-170, 1989 (in Japanese with English abstract).

Tanaka, H. and T. Kobayashi, Paleomagnetism of the late Quaternary Ontake Volcano, Japan: directions, intensities, and excursions, Earth Planets Space, 55, 189-202, 2003.

Tatsumi, Y. and H. Tsunakawa, Cenozoic volcanism, stress gradient and back-arc opening in the North Island, New Zealand: Origin of TaupoRotorua Depression, The Island Arc, 1, 40-50, 1992.

Teanby, N., C. Laj, D. Gubbins, and M. Pringle, A detailed palaeointensity and inclination record from drill core SOH1 on Hawaii, Phys. Earth Planet. Inter., 131, 101-140, 2002.

Verosub, K. L. and S. K. Banerjee, Geomagnetic excursions and their paleomagnetic record, Rev. Geophys. Space Phys., 15, 145-155, 1977.

Watkins, N. D. and J. Nougier, Excursions and secular variation of the Brunhes epoch geomagnetic field in the Indian Ocean region, J. Geophys. Res., 78, 6060-6068, 1973.

Wood, I. A., Thermoluminescence dating of the Auckland and Kerikeri basalts fields, MSc thesis, University of Auckland, 1991.

Yamamoto, Y., K. Shimura, H. Tsunakawa, T. Kogiso, K. Uto, H. G. Barsczus, H. Oda, T. Yamazaki, and E. Kikawa, Geomagnetic paleosecular variation for the past $5 \mathrm{Ma}$ in the Society Islands, French Polynesia, Earth Planet. Space, 54, 797-802, 2002.

Yamamoto, Y., H. Tsunakawa, and H. Shibuya, Palaeointensity study of the Hawaiian 1960 lava: implications for possible causes of erroneously high intensities, Geophys. J. Int., 153, 263-276, 2003.

N. Mochizuki (e-mail: nmochi@geo.titech.ac.jp), H. Tsunakawa, H. Shibuya, T. Tagami, A. Ozawa, J. Cassidy, and I. E. M. Smith 